\title{
A Glance at Tourism Economics over the last decade
}

Un aperçu de l'économie du tourisme de la dernière décennie

Samuel Bates

\section{OpenEdition}

Journals

Electronic version

URL: http://journals.openedition.org/tourisme/3366

DOI: $10.4000 /$ tourisme.3366

ISSN: 2492-7503

Publisher

Éditions touristiques européennes

\section{Electronic reference}

Samuel Bates, "A Glance at Tourism Economics over the last decade", Mondes du Tourisme [Online]

18 | 2020, Online since 01 March 2021, connection on 15 March 2021. URL: http://

journals.openedition.org/tourisme/3366 ; DOI: https://doi.org/10.4000/tourisme.3366

This text was automatically generated on 15 March 2021.

\section{cc)}

Mondes du tourisme est mis à disposition selon les termes de la licence Creative Commons Attribution - Pas d'Utilisation Commerciale - Pas de Modification 4.0 International. 


\title{
A Glance at Tourism Economics over the last decade
}

Un aperçu de l'économie du tourisme de la dernière décennie

\author{
Samuel Bates
}

\section{Introduction}

1 Tourism economics remains relatively young as an integral part of economic analysis. This status within economic research has emerged since the turn of the 1980s-1990s through three journals dedicated to tourism: Tourism Management in 1982, International Journal of Contemporary Hospitality Management in 1989 and Tourism Economics in 1995. These contribute to the visibility of tourism issues in economic research, issues which were previously published by historical channels such as: Journal of Travel Research since 1968 or Annals of Tourism Research since 1973. Thereafter, interest in economics in the tourism phenomenon has been continuous.

2 The objective here is to give an insight into the trends in contemporary research conveyed through English-language journals. The literature review goes beyond the aforementioned journals, while remaining within reference resources that are influential in economics. To do this, a freeze frame is taken over a decade of publications between the last two global upheavals (i.e., the subprime crisis in 2007 and the Covid-19 crisis since 2020) that have affected tourism in various ways.

3 A synoptic picture of this research area is thus drawn up to synthesise the elements that remain consensual, to isolate the roots of the debate from an economic point of view, and to suggest some research perspectives. 


\section{Research in tourism economics between the two crises}

4 The analysis here exclusively considers journals that are listed in the French National Centre for Scientific Research's (CNRS) classification of reference journals for economics and management. For the most part, these journals publish papers in English. This ranking of a French research institution is largely based on the Journal of Economic Literature classifications.

5 Therefore, the analysis excludes the 13 journals (out of 800 ) of the CNRS ranking that publish, more or less frequently, French-written papers on tourism issues: Développement durable et territoires; Économie et statistique; Économie rurale; Entreprises et histoire; Histoire, économie et société; Innovations: Revue d'économie et de management de l'innovation; Mondes en développement; Natures, sciences, sociétés; Région et développement; Revue d'économie du développement; Revue d'économie industrielle; Revue d'économie régionale et urbaine; Revue internationale PME; Travail et emploi. Journals that exclusively concern management sciences without economics are also excluded regardless of the main language of publication.

6 Papers of interest deal explicitly with tourism in the body text and are published between 2008 and 2019. A minimal frequency of 15 occurrences for the word "touris*" (i.e., tourism and its derivatives) in the body text is a prerequisite to build a short list of papers. To focus on the most influential contributions in tourism economics, an additional double selection is implemented:

7 (i) Journals that provide a forum for tourism are selected by applying the minimum threshold of 15 publications over the period from 2008 to 2019.

8 Two types of journals are distinguished:

a. First type: 5 journals that are exclusively dedicated to tourism. They are listed as follows, from a decreasing total number of papers: Tourism Management, Tourism Economics, Annals of Tourism Research, Journal of Travel Research, International Journal of Contemporary Hospitality Management.

b. Second type: 19 journals that publish contributions beyond tourism. They are listed according to the same criterion: Journal of Environmental Management, Ecological Economics, Applied Economics, Journal of Environmental Planning \& Management, Climatic Change, Energy Policy, Urban Studies, Environment \& Planning A, Economy \& Space, Applied Economics Letters, Economic Modelling, International Journal of Urban \& Regional Research, Environmental Pollution, Ecological Modelling, Third World Quarterly, Transportation Research Part A Policy \& Practice, Journal of Cultural Economics, Natural Resources Forum, Regional Studies, Technological Forecasting \& Social Change.

9 (ii) To balance papers visibility in tourism between both types of journals, influential papers are identified from a minimal threshold of 150 citations when they are published in $1^{\text {st }}$ type journals, against 15 citations when they are published in $2^{\text {nd }}$ type journals.

10 These selection criteria help to extract publications in journals of reference with minimal popularity among researchers, while reflecting the diversity within the contemporary English language economic research. Consequently, 596 papers are identified, including 290 publications in $2^{\text {nd }}$ type journals. Table 1 and Figure 1 summarise the bibliometric information according to CNRS research fields. 
Table 1. Bibliometric data on tourism economics

\begin{tabular}{|c|c|c|c|}
\hline JOURNAL TITLE & $\begin{array}{l}\text { NUMBER OF } \\
\text { PAPERS }\end{array}$ & JOURNAL TITLE & $\begin{array}{l}\text { NUMBER OF } \\
\text { PAPERS }\end{array}$ \\
\hline Tourism Management & 160 & Natural Resources Forum & 9 \\
\hline Annals of Tourism Research & 86 & $\begin{array}{l}\text { Transportation Research Part A } \\
\text { Policy \& Practice }\end{array}$ & 9 \\
\hline Applied Economics & 61 & Urban Studies & 9 \\
\hline Journal of Travel Research & 54 & Journal of Cultural Economics & 8 \\
\hline $\begin{array}{l}\text { Journal of Environmental } \\
\text { Planning \& Management }\end{array}$ & 38 & Regional Studies & 8 \\
\hline $\begin{array}{l}\text { Journal of Environmental } \\
\text { Management }\end{array}$ & 27 & Energy Policy & 7 \\
\hline Ecological Economics & 22 & $\begin{array}{l}\text { Environment and Planning A } \\
\text { Economy \& Space }\end{array}$ & 7 \\
\hline Ecological Modelling & 20 & $\begin{array}{l}\text { Technological Forecasting \& Social } \\
\text { Change }\end{array}$ & 7 \\
\hline Climatic Change & 16 & $\begin{array}{l}\text { International Journal of Urban \& } \\
\text { Regional Research }\end{array}$ & 6 \\
\hline Economic Modelling & 11 & Applied Economics Letters & 3 \\
\hline Environmental Pollution & 11 & $\begin{array}{lr}\text { International } & \text { Journal of } \\
\text { Contemporary } & \text { Hospitality } \\
\text { Management } & \end{array}$ & 3 \\
\hline Third World Quarterly & 11 & Tourism Economics & 3 \\
\hline
\end{tabular}

11 Given the distribution of these journals in the CNRS classification, the literature of interest distinguishes three groups of research fields:

- The pilot group entitled "Urban, spatial and regional economics, transportation and tourism". This is the historical research channel in tourism economics. Publications originating from:

1) Journals that are exclusively dedicated to tourism;

2) Journals that focus on tourism among other topics.

- The motor group entitled: "Environment, Agriculture, Natural resources, Energy".

- The follower group which gathers the remaining research fields: "General economics", "Macroeconomics, international \& monetary economics", "Development \& transition economics", "Industrial organization" and "Innovation \& entrepreneurship". 
Figure 1. Fields share in tourism economics
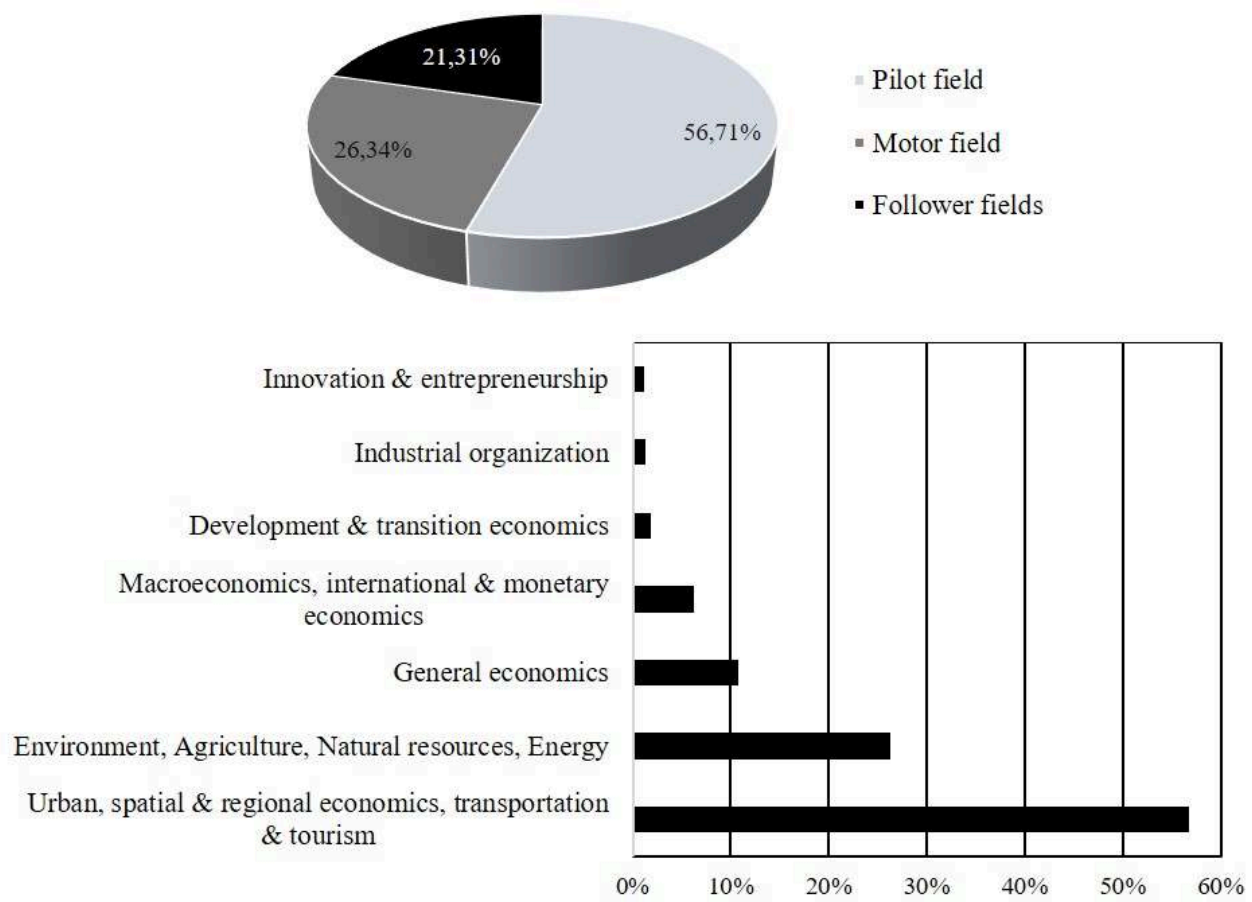

12 The following synoptic table summarises this literature using the salient topics and analysis grids that are mobilised during the past decade.

Table 2. Synoptic picture of tourism economics

\begin{tabular}{|c|c|c|c|c|}
\hline $\begin{array}{l}\text { FIELDS } \\
\text { GROUP }\end{array}$ & MAIN ISSUE & SPACE & SCALE & $\begin{array}{l}\text { DISCIPLINARY } \\
\text { VIEWPOINT }\end{array}$ \\
\hline \multirow[t]{2}{*}{ Pilot } & $\begin{array}{l}\text { Evolutions in tourism Industry } \\
\text { through } \\
\text { Communication Technology (ICT) }\end{array}$ & Multiple space & $\begin{array}{l}\text { Micro/ } \\
\text { Meso }\end{array}$ & $\begin{array}{l}\text { Economics- } \\
\text { management }\end{array}$ \\
\hline & $\begin{array}{l}\text { Urban tourism } \\
\text { (cities dynamics impacted by } \\
\text { tourism) }\end{array}$ & $\begin{array}{l}\text { From world } \\
\text { cities to regional } \\
\text { scale* }\end{array}$ & $\begin{array}{l}\text { Meso/ } \\
\text { Macro }\end{array}$ & $\begin{array}{l}\text { Economics- } \\
\text { geography }\end{array}$ \\
\hline Motor & Tourism sustanability & $\begin{array}{l}\text { From regional } \\
\text { scale* to planet }\end{array}$ & $\begin{array}{l}\text { Micro/ } \\
\text { Meso/ } \\
\text { Macro }\end{array}$ & $\begin{array}{l}\text { Economics- } \\
\text { environmental } \\
\text { sciences }\end{array}$ \\
\hline Followers & $\begin{array}{l}\text { Causal chain between tourism, } \\
\text { international trade, growth, } \\
\text { poverty }\end{array}$ & $\begin{array}{l}\text { National } \\
\text { boundaries }\end{array}$ & Macro & Economics \\
\hline
\end{tabular}

* within national boundaries 
13 Studies in the pilot fields emphasise the various ways to transform the tourism industry with the use of Information Communication Technologies (ICT). Some implications for the management practices of tourism providers are studied in particular (Stephen et al., 2008; Xiang and Gretzel, 2010; Filieri and Mc Leay, 2013; Law et al., 2014; Liu and Park, 2015). Specifically, changes in the behaviour of tourists when choosing their destination, and also evolutions in their ex-post attitudes are studied. Consequently, authors scrutinise the causal chain that associates both internal and external relevant determinants of consumers' choices (Geng-Qing Chi and Qu, 2008; Chen and Chen, 2010; Yuksel et al., 2010; Qu et al., 2011; Sparks and Browning, 2011; Wing Sun Tung and Ritchie, 2011; Prayag and Ryan, 2012; Zhang et al., 2014). This detailed knowledge about consumers' behaviour should help the diversity of providers to adapt their sales and promotion strategies to survive the competition. The analysis of residents' tolerance for tourism is also studied, mainly to identify strategies that protect the physical, social, and cultural capital of the destination and avoid local reluctance to tourism (Nunkoo and Gursoy, 2011; Deery et al., 2012; Kim et al., 2013; Lee, 2013). The ambition here comes down to thinking about commercial strategies that merge residents' expectations on tourism at a local, as well as national, scale with heterogeneous needs of tourism consumers.

14 The sharing economy is emphasised as an exemplary illustration. On the one hand, the sharing economy is a conspicuous example of the squeezing process of traditional tourism intermediation between touristic supply and demand (Munar and Jacobsen, 2014; Ert et al., 2016; Tussyadiah and Pesonen, 2016). On the other hand, the sharing economy serves as a holistic illustration of the impacts of tourism on host cities and their periphery.

15 This last topic is still on the top edge of journals that are not exclusively dedicated to tourism in the field, "Urban, spatial and regional economics, transportation and tourism" (González, 2011; Campa et al., 2016; Füller and Michel, 2014 for references). Here, the dynamics of host areas is analysed through institutionalist perspectives of space and industrial changes along the value chain of tourism. Within this literature, the study of destination governance has progressed considering the societal impacts of research. Nevertheless, transport issues largely dominate the debate on tourism accessibility. This is even more conspicuous than through real estate with its implications for regional planning and for cities' identities. The authenticity of locations comes up against the cultural standardisation of cities that embrace economic, social, and cultural codes of international tourism. To identify opportunities for expanding tourism in new territories or for transforming destinations, a higher issue emerges: the (re)location of tourist services and the identification of sites or even touristic destinations for the future on a macroeconomic scale.

16 This last issue is central for the motor research field (Perch-Nielsen et al., 2010; Bury et al., 2011). Issues around strong sustainability of the tourism industry hide behind worries about economic opportunities and the geographical location for future activities. These issues cover economic, social, environmental, and cultural dimensions, as soon as the destinations are the focus (Baral et al., 2008; Beharry-Borg and Scarpa, 2010; Liu et al., 2010; Deyà Tortella and Tirado, 2011; Coria and Calfucura, 2012; Mendoza-González et al., 2012; Gössling, 2013; Iniesta-Arandia et al., 2014; Xiong et al., 2018). The scientific challenge relates to the complexity of the human-nature systems 
to be understood around climate issues, negative environmental externalities of tourism, and the protection of natural and cultural capital that host territories support.

The follower research fields also share the issue of negative tourism externalities, insofar as the objective is to specify the way in which these externalities impact the macroeconomic causality between tourism - international trade - economic growth (Neves Sequeira and Maças Nunes, 2008; Katircioglu, 2009; León et al., 2014).

Figure 2. Macroeconomic causality in tourism liquidity circuit

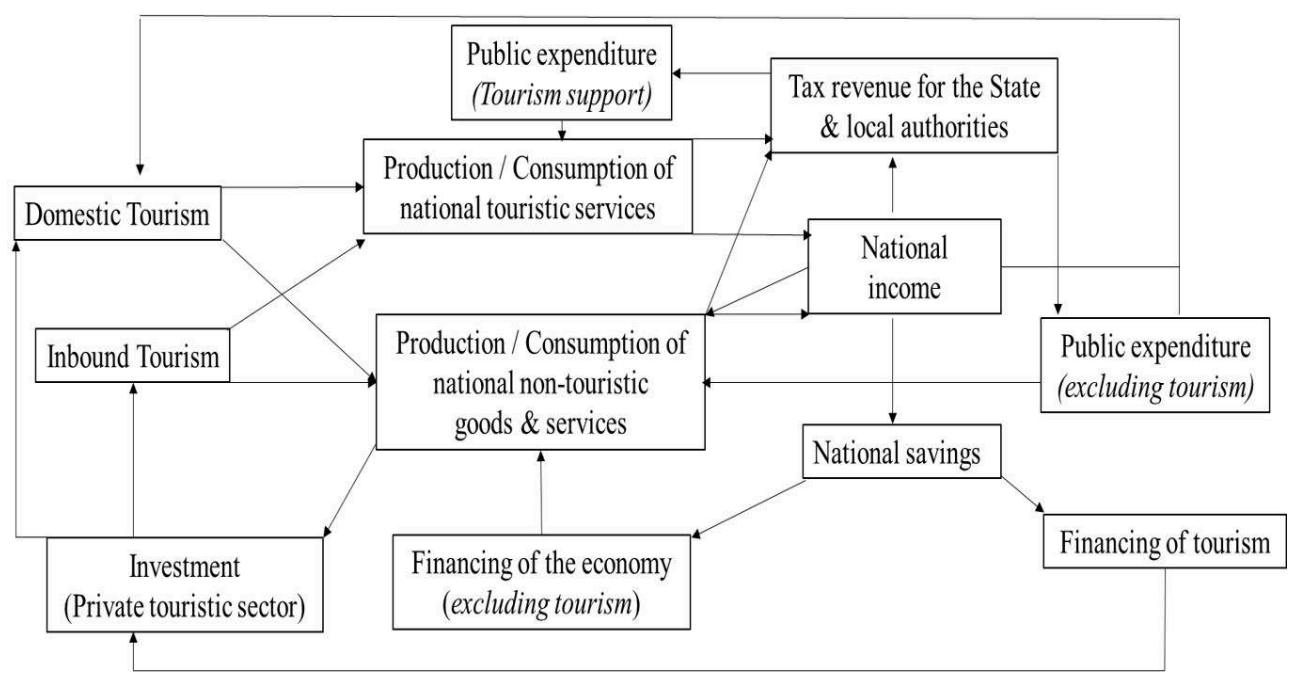

The arrival of international tourists smoothed by domestic tourism leads to a self-sustained liquidity flow so that the collected revenues for residents (either in the private sector or in the public one) must exceed in value initial expenses that are required to attract tourists to the destination.

More broadly, endogenous (for example, corruption, Poprawe, 2015) or exogenous (for example, terrorism, Feridun, 2011) disturbances also discriminate between country effects in the previous causal chain. All in all, the capacity of tourism to initiate development and to reduce poverty, particularly in southern countries, is still debatable, since the robustness of macroeconomic causal chains to global risks should be reassessed.

\section{Methodological trends}

Since the 1980s, computer progress and dedicated software have enhanced advances in tourism economics. They help to renew experimentation based on quantitative or qualitative assessment. A consensus has emerged on the interdependencies between key macroeconomic variables relating to growth, international trade, and tourism, notably through the price competitiveness of destinations (exchange rate and inflation to a lesser extent). At a microeconomic level, the determining factors of tourism access cost are hardly debatable.

Over the past decade, regardless of the (micro vs. macro) scale of analysis, progress has mainly been based on four methods:

- Composite indexes to synthesise multidimensional information and ease multicriteria interpretations;

- Data analysis from traditional surveys, or to an increasing extent, from online surveys; 
- Time series econometrics and increasingly panel data to solve the limited sample sizes through the time dimension;

- Calibration and simulation to capture future evolutions instead of econometric forecasting;

- Heuristic models to depict causality networks, correlation or more generally interdependences, whether they are empirically tested or deduced from a thematic literature review. empirical testing tools. is no longer a debate. international tourism. and international tourism. al., 2018). quality.

The mainstream generalises quantitative methods, including for processing qualitative data. Additionally, a combination of two or even three methods are used to establish sequential protocols for testing hypotheses. Although less frequently used, metaanalyses are emerging to establish the robustness of interpretations to a variety of

The complexity in macro-models, through computable general equilibrium models for instance, is no longer increasing. But this diversity of methods should not erase costbenefit analyses at the micro or meso levels, nor satellite accounts at a macro level.

However, all these advances do not resolve some analytical limitations. With no exhaustivity, one can cite for instance:

(i) The debate on tourism definition. This issue only makes sense today for interdisciplinary dialogue because, from an economic viewpoint, the tourism definition

5 The UNWTO (World Tourism Organization) definition remains the benchmark in economics for comparing destinations' performance using a harmonised computation basis. Being a tourist means traveling outside of your usual residence for a period of less than one year and for a reason that is unrelated to paid work for an organisation located in the host destination. If this definition is perfectly suited to the original economic interest of tourism ${ }^{1}$, domestic tourism (not considered by the UNWTO) is recognised in the economic analysis. This serves as a defensive tourism strategy that helps stabilise the volatility and seasonality of the liquidity flows earned from

However, a harmonised tourism accounting between States is still expected to refine the economic assessment of the performance of destinations, by cumulating domestic

Several pitfalls stand against this objective. They are related to the quality and blurred sense of some available statistics (Volo and Giambalvo, 2008; Stock et al., 2017; Pratt et

Firstly, considering the issue of pure measurement, statistical institutions practice the WTO definition differently. Measurement quality does not always meet the following criteria: relevance and helpfulness, comprehensiveness, simplicity, ease of interpretation, accuracy, methodological soundness, and computational robustness.

Secondly, unequal financial support to national statistical institutions creates a discrepancy between developed and developing countries. However, even in developed states, the political use of statistical measurement hinders a continuous assessment of

While hoping for an institutional overhaul of statistics, some mathematical tricks remain unexplored to check and correct some approximations. Among others, filtering 
methods and/or unobserved component modelling could reveal hidden tourism and mitigate over/underestimations of tourism performance.

31 Nevertheless, we should keep in mind that accounting artefacts are unavoidable when any social phenomenon is assessed from discrete time computations. However, this does not go so far as to disqualify measurement in tourism studies.

(ii) The value assessment along the tourism supply chain remains a challenge, especially if strong sustainability of tourism is at stake.

Specifically, the money valuation of produced or destroyed values through the social, environmental, and cultural dimensions remains a crucial challenge beyond the economic dimension. This assessment is adorned with time complexity, coupled with a destination's life cycle, long run transmission of the tourism support (i.e., the destination) to future residents and short run anticipation of irreversibility.

\section{Future prospect}

34 To make progress in the economic analysis of tourism, a reading grid is here suggested, starting from one of the salient features of the past decade: the confirmed reconfiguration of tourism intermediation. This reading grid adapts the analysis of financial intermediation-disintermediation-(re)intermediation of monetary and financial economics to the tourism industry. Figure 3 summarises this reading grid based on an accounting approach.

Figure 3a. Accounting approach of tourism intermediation (1/3)

DIRECT TOURISM
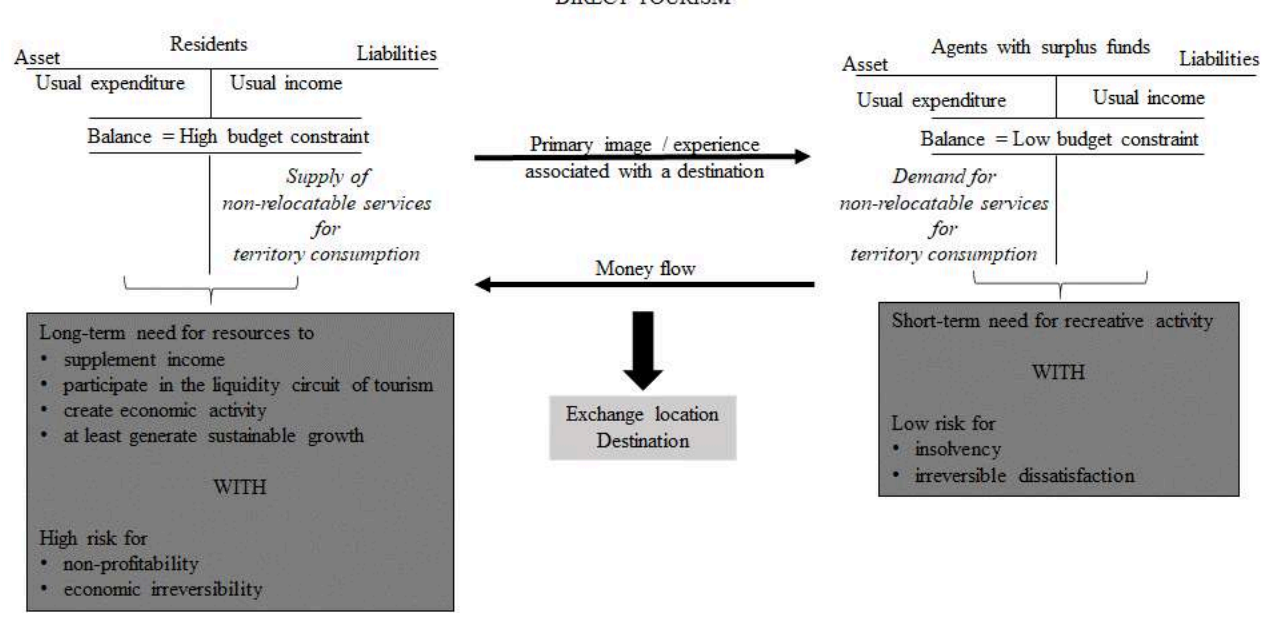
Figure 3b. Accounting approach of tourism intermediation (2/3)

INTERMDIATE TOURISM: TRADITIONAL INTERMEDIATION

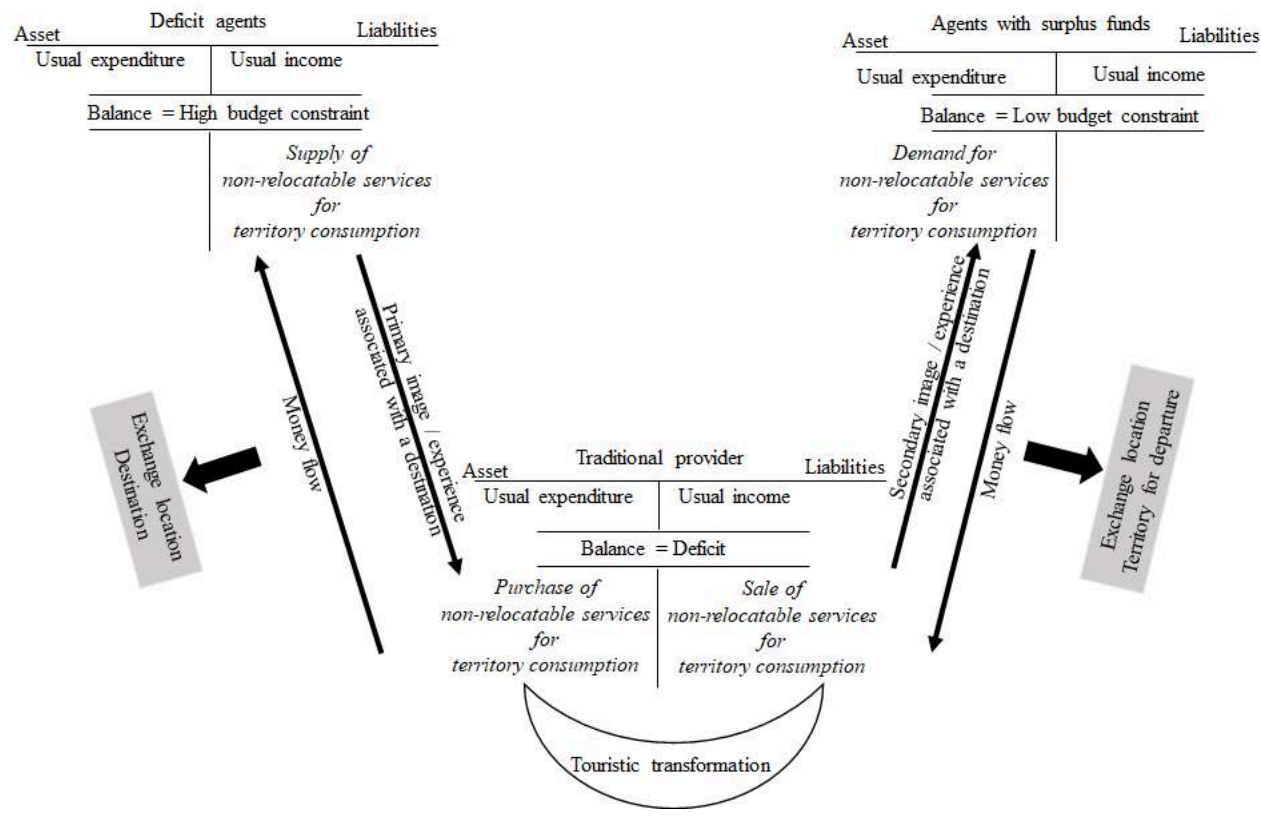

Figure 3c. Accounting approach of tourism intermediation (3/3)

INTERMDIATE TOURISM: ONLINE INTERMEDIATION

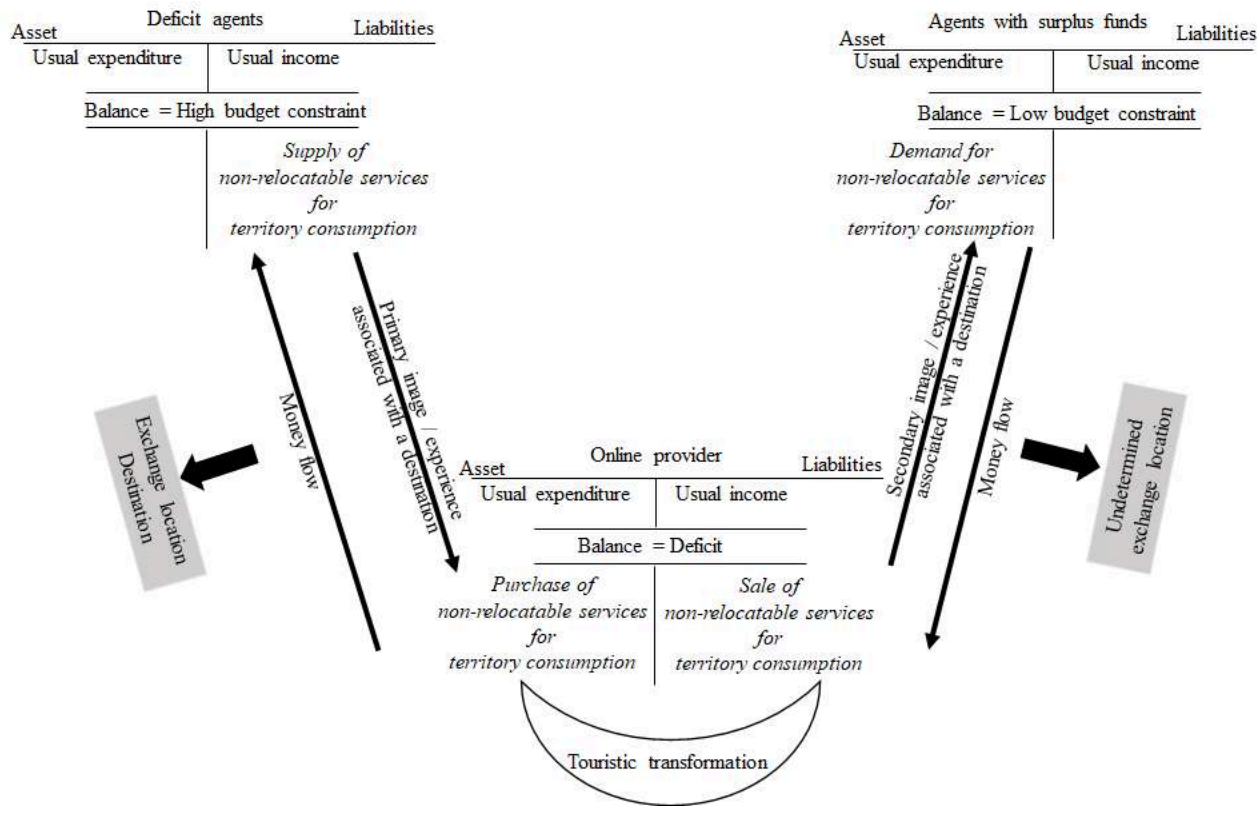

- Agents with surplus funds live in tourism departure territories. These are households with a great saving capacity. They are mainly located in northern countries, and more recently in China for international tourism. Considering domestic tourism, they are mainly located in national territories with a relative high purchasing power. These agents can relax their budget constraints and benefit from a large share of leisure. They aggregate the tourist demand.

These agents wish to benefit from recreational activities (short-term projection) without losing too much money but with a memorable experience of the destination promised. The 
destination is considered as a less risky "consumption product", which results in a very convincing money value for payment consent.

- Agents who are structurally in need of supplementary income, either improved economic situation or guaranteed economic existence. These are the private residents of touristic destinations: (i) households that envision tourism as an opportunity to relax their very restrictive budget constraints; (ii) companies that constantly renew their investment locally for competition in the tourism sector. These are also host States which expect to cumulate foreign currencies and increase the circulating volume of liquidity inside the national circuit, which a capitalist monetary economy requires.

For this group of agents, the risk to invest time and money in the tourism industry is high, due to potential sunk costs and negative social, environmental, and cultural externalities. However, the game is worth the candle so long as liquidity is at least collected. Tourism expansion is then a very risky, but potentially very profitable, activity for community residents. Tourism here participates in a long-term projection.

- Tourism (online vs. traditional) intermediaries carry out a tourism transformation in the sense that they make compatible expectations that are not compatible between residents and visitors. On the one hand, residents have long term rationale with very risky expectations of profitability when exploiting their territory. On the other hand, the benefit of tourists seems selfishly short-term without real risk-taking but with the urge to live a short but unforgettable experience. This tourism transformation structures the assets and liabilities of tourism intermediaries. On the asset side, the pooled contracts of service supply are signed with resident players in touristic destinations. These contracts build the demand for exploiting the (primary) destination image or promised experience. Residents supply this service in exchange for a monetary counterpart. On the liabilities side, the pooled (secondary) service contracts are dedicated to tourists in exchange for a payments counterpart of the tourism transformation. The activity of tourism transformation alters the customers' perceived value of tourism services and influences their payment consent. information on destinations. These elements impact the destination choice. This legitimises the existence of tourism intermediation, even though accessing information is no longer the issue, thanks to the volume of resources conveyed simultaneously through ICTs. Sustainability of tourism intermediation depends on the ability to pool and manage identified risks, to acquire expertise on collecting and processing information, to respond efficiently to customers.

From this point, the issue of location exchanges can be reinterpreted as follows:

Markets generally structure exchanges in economics by precisely answering the question: where does money go? In tourism economics, however, 'destination' is a substitute for 'market'. Thus, any destination comes to life through the decisions of the dominant players (not only the supplier of relevant tourist services in relation to demand but also the institutional process for tourism development). Institutions are established through the principal means of financing tourism (either direct, or traditional intermediary or online intermediary).

Direct tourism has drawbacks: transaction costs, asymmetry in the idiosyncratic From this point of view, a universal provider is no longer illusory alongside online providers, knowing the certain death of specialists in traditional intermediation. Indeed, traditional and online intermediation convey fundamental but complementary information on destinations differently. Going on the extreme viewpoint, a universal intermediary would be able to supply traditional and online intermediation but would 
also be able to position itself on direct tourism. As a result, a new cycle of tourism (re-)intermediation could occur with a partial control recovery of digital communication. This would redistribute power over the destination ("market power") between the various tourism intermediaries and would change the institutional process within the tourism industry.

Beyond this conjecture and considering the accounting vision of figure 3, customers' payment consent is obtained if the perceived value of the destination image or the promised experience, will be greater than the effective price. Reciprocally, the residents' consent to host tourists, or even the consent of the state, is obtained if the lost value is lower than the price to be received from tourism. An issue arises: value perception, which assumes two sub-issues: agents' perception and the accounting system of money valuation.

The first sub-issue is a lively research topic that mixes economics and management. The objective is to clarify our knowledge of cognitive and affective determinants that trigger the spending behaviours of both providers and customers. These determinants interact with exogenous factors that state the informational context for decisionmaking. On this point, new developments in experimental economics, based on new computer progress, should lead at a micro scale to the frontier of psychology, in addition to the more aggregated level of sociology.

The second sub-issue requires more connections between economics and environmental sciences to tackle the feasibility of strong sustainability through the tourism industry. An immediate issue is to harmonise the computation of touristic values, which goes beyond a money valuation of the natural capital that is exploited or sacrificed through tourism practices. Attempts, such as Remme et al. (2015), require further analyses. The harmonising issue is essential to maintain the ability to compare tourism performance and consequently to identify operational tourism strategies conditionally to contexts. A holistic system of tourism accounting that also integrates social and cultural values would be ideal in the long run but combining environmental and economic values could be a first step.

These perspectives should renew the current dialogue between economics and other social sciences. This should lead to revisiting the disciplinary intersections between multidisciplinarity, interdisciplinarity and transdisciplinarity (Darbellay and Stock, 2011; Okumus et al., 2018).

It is still true that a whole series of determinants and characteristics around the concept of destination escape the basic microeconomic and macroeconomic analysis. To solve this inadequacy, the main solution in economics is to internalise contributions from other social sciences such as history, geography, sociology, law etc. Nevertheless, the very recent methods of analysis tend to allow this trend of internalising other sciences in tourism economics differently. Beyond opportunities conceivable in tourism from experimental economics, the new age of big data will ease the pooling of individual, temporal, and geolocation data, such that the economic analysis will cover more and more historical and geographic complexity. From this point of view, an extension towards exact sciences (mathematics and computer science) becomes an additional horizon for interdisciplinarity in tourism studies. 


\section{Concluding discussion}

After this literature review from English-language papers that are published between 2008-2019, and after the suggested prospects, the assertion of Candela and Figini (2012, p.9) still applies: "Tourism economics is to economics what applied economics is to pure economics". Pure economics abstracts the essential assumptions that ease understanding of the foundations of economic evolutions independently from specific contexts. On the contrary, applied economics grasps each specific reality through field observations. Hence, tourism economics develops analysis grids that are specific to studied contexts, which keeps a margin for deviating from some general or basic hypotheses in economics.

Besides, wealth surplus that is extracted from the tourism supply chain still particularly matters in the current capitalist economy. Nevertheless, beyond the wealth creation and the corresponding liquidity circulation inside destinations, the transcendental issue is now the capacity of tourism to preserve a scarce resource: the multidimensional value of destination.

The time has undoubtedly come to initiate a fourth phase in tourism research. This consists of back to renewed basics after the first three historical phases mentioned in (Dallerbay and Stock, 2011): (1) holistic vision of tourism systems, (2) multidisciplinarity and (3) interdisciplinarity.

The research agenda is now to keep a systemic view of tourism. "Tourism is currently a complex and globalized phenomenon with demonstrated socio-economic importance" (Darbellay and Stock, 2011, p.441). This is a network of actors with divergent interests in differentiated practices and which is driven by heterogeneous rationality. The ecosystem of actors acts through different dimensions (economic, social, environmental, political, and cultural), from various scales (micro, meso, macro), and from distinct spaces.

However, while the resulting complexity is often mentioned, suitable tools are rarely mobilised to study complexity in tourism systems. This is the reason why network sciences (Baggio et al., 2010) and/or complexity sciences must now be seized to constitute a common base for interdisciplinary dialogues.

However, scientific innovations are needed to enforce a renewal in the fourth phase of tourism research. The last decade invites us to do so, insofar as tourism systems are subject to all global risks:

i. systemic financial risks like the subprime crisis;

ii. pandemic contagion such as Covid-19 (Richard et al., 2020; Sigala, 2020; Zenker and Kock, 2020; Zheng et al., 2020);

iii. technological risks that involve adopting the right technical turns on time;

iv. cybercrime driven by digitalised tourism practices;

v. political risks ranging from civil insecurity to political instability passing through disruptions in institutional frameworks of economic activity;

vi. climate change with the uncertain local impact of a global but certain phenomenon (Ruhanen, 2015; Gössling and Highman, 2020).

These events may be external to tourism systems but share our low capacity to predict their location, frequency, and impact on the value of destinations. Our own limited 
knowledge of tourism systems adds to these uncertainties. The key limitation of our knowledge relates to the ability to assess the objective and perceived values that are driven through tourist flows: a context of high uncertainty.

Therefore, ensuring appropriate governance of tourism systems requires progressing in our ability to assess their current state, as well as the state of sub-systems. Two alternatives are conceivable. On the one hand, a specific tourism accounting that endogenizes economic, social, environmental, and even cultural values. On the other hand, composite indexes that build a grid of multi-criteria decision support. The second alternative is more explored than the first (Mendola and Volo, 2017, for instance). However, analyses mostly remain at the stage of a static description of the state of systems, whereas external and internal risks and uncertainties call for a dynamic assessment to serve anticipatory governance.

The knowledge of the evolutionary drivers of tourism systems state becomes a key issue to be grasped from a holistic vision in order to schedule transitions, or even transformations, that renew destinations and tourist practices on time. These transitions can be financial, numerical, ecological, or cultural and are required to sustain destination values where they are either economic, social, environmental, or cultural dimensions, and despite the aforementioned uncertainties.

53 All in all, the scientific issue consists in generalising integrated models of the different components of tourism systems on which each science provides specific knowledge. In this context, economics, through its faculty to encompass other disciplines, is a legitimate way to help stakeholders' decision-making in tourism systems. Solutions are provided to manage scarce and constrained resources.

Consequently, some paradigmatic evolutions are necessary:

A reversed interpretation such that tourism values of destinations is no longer conceived as an output but as the transcendent input to be preserved and such that the identity of destinations is no longer conceived as a resource but as an output to be renewed.

Managing identity under value constraints should be based on a convenient structuring between the ecological system of nature and the economic system. This gives relevance to study tourism systems as ecological and social systems. By doing so, the implied rebalancing between top-down and bottom-up research approaches is a call for collaborations between researchers who are involved in tourism management and tourism studies and for extending the number of disciplines that are involved in tourism research beyond social sciences.

These paradigm shifts are feasible but only possible if tourism institutionalism is revisited in the current capitalism. The political stake here is to extricate from the resistance of national and international regulatory bodies that push to assess tourism only through the objectives of growth in the flow of travellers and / or liquidity. The time has come to gaze towards indicators and evaluation methods that intend to promote flow stability at a minimal cost in terms of vulnerability for tourism systems. Following this direction, economics could serve to promote governance of viability and resilience of tourism systems, in a context of both the scarcity of resources and the scarcity of output growth. Subjugating political and institutional mechanics of tourism to these paradigm shifts should turn away from overtourism (Oklevik et al., 2019; Séraphin et al., 2019). 

realism. Economics here will help to stress the correct constraints to identify the right set of decision rules that can sustain the preservation of destination values that are perceived by tourism stakeholders.

61 The prism of English-language research in economics is here adopted. But the same exercise with French-language research should also be considered to complete the research agenda by filling the hiatus of English-speaking productions that ignore French-language research.

\section{BIBLIOGRAPHY}

Rodolfo BAGGIO., Noël SCOTT and Chris COOPER, "Network science: A review focused on tourism", Annals of Tourism Research, 37, 2010.

Nabin BARAL, Marc J. STERN and Ranju BHATTARAI, “Contingent valuation of ecotourism in Annapurna conservation area, Nepal: Implications for sustainable park finance and local development", Ecological Economics, 66, 2008.

Nesha BEHARRY-BORG and Ricardo SCARPA, "Valuing quality changes in Caribbean coastal waters for heterogeneous beach visitors", Ecological Economics, 69, 2010.

Jeffrey T. BURY, Bryan G. MARK, Jeffrey M. MCKENZIE;Adam FRENCH, Michel BARAER, Kyung IN HUH, Marco Alfonso ZAPATA LUYO and Ricardo Jesús GÓMEZ LóPEZ, “Glacier recession and human vulnerability in the Yanamarey watershed of the Cordillera Blanca, Peru", Climatic Change, 105, 2011.

Juan L. CAMPA, María E. LÓPEZ-LAMBAS and Begoña GUIRAO, "High speed rail effects on tourism: Spanish empirical evidence derived from China's modelling experience", Journal of Transport Geography, 57, 2016.

Guido CANDELA and Paolo FIGINI, The Economics of tourism destinations, Springer, 2012. 
Ching-Fu CHEN and Fu-Shian CHEN, "Experience quality, perceived value, satisfaction, and behavioral intentions for heritage tourists". Tourism Management, 31, 2010.

Classement des revues de référence en économie-gestion du CNRS (2020) : https:// sites.google.com/site/section37cnrs/Home/revues37

Jessica CORIA and Enrique CALFUCURA, "Ecotourism and the development of indigenous communities: The good, the bad, and the ugly", Ecological Economics, 73, 2012.

Frédéric DARBELLAY and Mathis STOCK, “Tourism as complex interdisciplinary research object”, Annals of Tourism Research, 39, 2011.

Margaret DEERY, Leo JAGO and Liz FREDLINE, "Rethinking social impacts of tourism research: A new research agenda", Tourism Management, 33, 2012.

Eyal ERT, Aliza FLEISCHER and Nathan MAGEN, "Trust and reputation in the sharing economy: The role of personal photos in Airbnb", Tourism Management, 55, 2016.

Mete FERIDUN, "Impact of terrorism on tourism in Turkey: Empirical evidence from Turkey", Applied Economics, 43, 2011.

Robert FLETCHER, Ivan M. MAS, Asunción BLANCO-ROMERO and Macià BLÁZQUEZ-SALOM, “Tourism and degrowth: An emerging agenda for research and praxis", Journal of Sustainable Tourism, 27, 2019.

Raffaele FILIERI and Fraser MCLEAY, "E-WOM and accommodation: An analysis of the factors that influence travelers' adoption of information from online reviews", Journal of Travel Research, 53, 2013.

Henning FÜLLER and Boris MICHEL, “'Stop being a tourist!' New dynamics of urban tourism in Berlin-Kreuzberg”, International Journal of Urban and Regional Research, 38, 2014.

Christina GENG-QING CHI and Hailin QU, "Examining the structural relationships of destination image, tourist satisfaction and destination loyalty: An integrated approach", Tourism Management, 29,2008

Sara GONZÁLEZ, "Bilbao and Barcelona 'in motion'. How urban regeneration 'models' travel and mutate in the global flows of policy tourism" Urban Studies, 48, 2011.

Stefan GÖSSLING and James HIGHAM, "The Low-Carbon Imperative: Destination Management under Urgent Climate Change", Journal of Travel Research, I-13, 2020.

Irene INIESTA-ARANDIA, Marina GARCÍA-LLORENTE, Pedro A. AGUILERA, Carlos MONTES and Berta MARTíNLÓPEZ, "Socio-cultural valuation of ecosystem services: Uncovering the links between values, drivers of change, and human well-being", Ecological Economics, 108, 2014.

Salih KATIRCIOGLU, "Tourism, trade, and growth: the case of Cyprus", Applied Economics, 41, 2009.

Kyungmi KIM, Muzaffer UYSAL and Joseph SIRGY, "How does tourism in a community impact the quality of life of community residents?", Tourism Management, 36, 2013.

Rob LAW, Dimitrios BUHALIS and Cihan COBANOGLU, "Progress on information and communication technologies in hospitality and tourism", International Journal of Contemporary Hospitality Management, 26, 2014.

Carmelo J. LEÓN, Jorge E. ARANA and Anastasia HERNÁNDEZ ALEMÁN, " $\mathrm{CO}_{2}$ Emissions and tourism in developed and less developed countries”, Applied Economics Letters, 21, 2014. 
Jing LIU, Zhiyun OUYANG and Hong MIAO, "Environmental attitudes of stakeholders and their perceptions regarding protected area-community conflicts: A case study in China", Journal of Environmental Management, 91, 2010.

Zhiwei LIU and Sangwon PARK, "What makes a useful online review? Implication for travel product websites", Tourism Management, 47, 2015.

Daria MENDOLA and Serena Volo, "Building composite indicators in tourism studies: Measurements and applications in tourism destination competitiveness", Tourism Management, 59, 2017.

Ana María MUNAR and Jens Kr. STEEN JACOBSEN, “Motivations for sharing tourism experiences through social media", Tourism Management, 43, 2014.

Tiago NEVES SEQUEIRA and Paulo MAÇAS NUNES, "Does tourism influence economic growth? A dynamic panel data approach", Applied Economics, 40, 2008.

Helga NOWOTNY, “The potential of transdisciplinarity”, Paris: Rethinking interdisciplinarity, 2003. Robin NUNKOO and Dogan GURSOY, "Residents' support for tourism an identity perspective", Annals of Tourism Research, 39, 2012.

Ove OKLEVIK, Stefan GösSLING, Michael C. HALL, Jens KRISTIAN, Steen JACOBSEN, Ivar PETTER GRøTTE and Scott MCCABE, "Overtourism, optimisation, and destination performance indicators: A case study of activities in Fjord Norway", Journal of Sustainable Tourism, 27, 2019.

Fevzi oKUMUS, Mathilda VAN NIEKERK, Mehmet ALI KOSEOGLU and Anil BILGIHAN, "Interdisciplinary research in tourism", Tourism Management, 69, 2018.

Sabine L. PERCH-NIELSEN, Bas AMELUNG and Reto KNUTTI, "Future climate resources for tourism in Europe based on the daily tourism climatic index", Climatic Change, 103, 2010.

Marie POPRAWE, "A panel data analysis of the effect of corruption on tourism", Applied Economics, 47, 2015.

Girish PRAYAG and Chris RYAN, “Antecedents of tourists' loyalty to Mauritius: The role and influence of destination image, place attachment, personal involvement, and satisfaction", Journal of Travel Research, 51, 2012.

Stephen PRATT and Denis TOLKACH, “The politics of tourism statistics", International Journal of Tourism Research, 20, 2018.

Annette PRITCHARD, Nigel MORGAN and Irena ATELJEVIC, "Hopeful tourism: A new transformative perspective", Annals of Tourism Research, 38, 2011.

Halin QU, Lisa Hyunjung KIM and Holly Hyunjung IM, “A model of destination branding: Integrating the concepts of the branding and destination image", Tourism Management, 32, 2011.

Roy P. REMME, Bram EDENS, Matthias SCHRÖTER and Lars HEIN, “Monetary accounting of ecosystem services: A test case for Limburg province, the Netherlands", Ecological Economics, 112, 2015.

Hugues SÉRAPHIN, Mustafeed ZAMAN, Sharon OLVER, Stéphane BOURLIATAUX-LAJOINIE and Frederic DOSQUET, "Destination branding and overtourism", Journal of Hospitality and Tourism Management, $38,2019$.

Marianna SIGALA, “Tourism and Covid-19: Impacts and implications for advancing and resetting industry and research", Journal of Business Research, 117, 2020.

Beverley A. SPARKS and Victoria BROWNING, "The impact of online reviews on hotel booking intentions and perception of trust", Tourism Management, 32, 2011. 
Mathis STOCK, Vincent COËFFE and Philippe VIOLIER, Les enjeux contemporains du tourisme : une approche géographique. Presses universitaires de Rennes, 2017.

Bartolomé Deyà TORTELLA and Dolores TIRADO, "Hotel water consumption at a seasonal mass tourist destination. The case of the island of Mallorca", Journal of Environmental Management, 92, 2011.

Lee TSUNG HUNG, "Influence analysis of community resident support for sustainable tourism development", Tourism Management, 34, 2013.

Iis P. TUSSYADIAH and Juho PESONEN, "Impacts of peer-to-peer accommodation use on travel patterns", Journal of Travel Research, 55, 2016.

Serena volo and Ornella GIAMBALvo, "Tourism Statistics: Methodological Imperatives and Difficulties: The Case of Residential Tourism in Island Communities", Current Issues in Tourism, 11, 2008.

Vincent WING SUN TUNG and Brent J.R. RITCHIE, "Exploring the essence of memorable tourism experiences", Annals of Tourism Research, 38, 2011.

Zheng XIANG and Ulrike GRETZEL, "Role of social media in online travel information search", Tourism Management, 31, 2010.

Xiong XIONG, Kai ZHANG, Xianchuan CHEN, Huahong SHI, Ze LUO and Chenxi wU, "Sources and distribution of microplastics in China's largest inland lake - Qinghai Lake”, Environmental Pollution, 235, 2018.

Atila YUKSEL, Fisun YUKSEL and Yasin BILIM, "Destination attachment: Effects on customer satisfaction and cognitive, affective, and conative loyalty", Tourism Management, 31, 2010.

Sebastian ZENKER and Florian коск, "The coronavirus pandemic - A critical discussion of a tourism research agenda", Tourism Management, 81, 2020.

Hongmei ZHANG, Xiaoxiao FU, Liping A. CAI and Lin LU, "Destination image and tourist loyalty: A meta-analysis", Tourism Management, 40, 2014.

Dani ZHENG, Qiuju LUO and Brent W. RITCHIE, “Afraid to travel after Covid-19? Self-protection, coping and resilience against pandemic 'travel fear"', Tourism Management, 83, 2021.

\section{NOTES}

1. An increase in the speed of liquidity circulating inside a territory so long as external funds come in.

\section{ABSTRACTS}

The objective is to carry out a freeze frame of the English-written literature in tourism economics from 2008 to 2019. This period is not trivial since the two crises at both ends of the spectrum are breakpoints in the continuous growth of the tourism industry. Using a disciplinary 
classification of reference journals and focusing on the most influential contributions for this literature, a synoptic table of the diversity of research fields in economics identifies: the main issues; the scales of analysis; the disciplinary interactions; and the methodological progress. From there, future research perspectives are outlined for the coming decade.

L'objectif est de réaliser un arrêt sur image sur la littérature anglaise en économie du tourisme de 2008 à 2019. Cette période n'est pas anodine puisque les deux crises se situant aux deux extrémités du spectre sont des points de rupture dans la croissance continue de l'industrie du tourisme. À partir d'une classification disciplinaire des revues de référence et se focalisant sur les contributions les plus influentes de cette littérature, un tableau synoptique de la diversité des domaines de la recherche en économie du tourisme identifie : les principaux enjeux, les échelles d'analyse, les interactions disciplinaires et les progrès méthodologiques. De là, des perspectives de recherches futures sont esquissées pour la prochaine décennie.

INDEX

Mots-clés: tourisme, science économique, littérature de langue anglaise, intermédiation touristique, valeurs d'une destination

Keywords: tourism, economics, English-written literature, tourism intermediation, destination values

\section{AUTHOR}

\section{SAMUEL BATES}

Professeur des universités

Sciences économiques

Université d'Angers (UFR ESTHUA Tourisme et culture), GRANEM

samuel.bates[at]univ-angers.fr 